\title{
Role of orf73 in the development of lambdoid bacteriophages during infection of the Escherichia coli host
}

\author{
Karolina Zdrojewska ${ }^{1 \dagger}$, Aleksandra Dydecka1+ ${ }^{\dagger}$ Bożena Nejman-Faleńczyk¹, Gracja Topka',

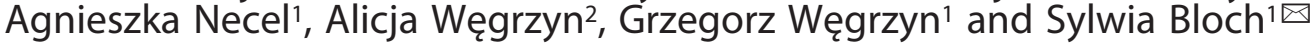 \\ 'Department of Molecular Biology, Faculty of Biology, University of Gdańsk, Gdańsk, Poland; '2Laboratory of Molecular Biology, Institute of Bio- \\ chemistry and Biophysics, Polish Academy of Sciences, Gdańsk, Poland
}

Shiga toxin-producing Escherichia coli (STEC) is a group of pathogenic strains responsible for human infections that result in bloody diarrhea and hemorrhagic colitis, often with severe complications. The main virulence factors of STEC are Shiga toxins encoded by the stx genes located in genomes of Shiga toxin-converting bacteriophages (Stx phages). These bacterial viruses are clustered in the lambdoid bacteriophage family represented by phage $\lambda$. Here, we report that expression of orf73 from the exo-xis region of the phage genome promotes the lysogenic pathway of development of $\lambda$ and $\$ 24_{B}$ phages. We demonstrated that the mutant phages with deletions of orf73 revealed higher burst size during the lytic cycle. Moreover, survival rates of $E$. coli infected with mutant bacteriophages were lower relative to wildtype viruses. Additionally, orf73 deletion negatively influenced the lysogenization process of $E$. coli host cells. We conclude that orf73 plays an important biological role in the development of lambdoid viruses, and probably it is involved in the network of molecular mechanisms of the lysis-vs.-lysogenization decision.

Key words: Lambdoid bacteriophages, Shiga toxin-producing Escherichia coli (STEC), exo-xis region, lysis-vs.-lysogenization decision

Received: 18 October, 2019; revised: 14 November, 2019; accepted: 16 November, 2019; available on-line: 26 November, 2019

$\square_{\text {e-mail: sylwia.bloch@biol.ug.edu.pl }}$

tThese authors contributed equally to this work.

Acknowledgements of Financial Support:

The costs of the article published as a part of the 44th FEBS Congress Kraków 2019 - From molecules to living systems block are financed by the Ministry of Science and Higher Education of the Republic of Poland (Contract 805/P-DUN/2019).

This research was funded by the National Science Center (Poland), grant no. UMO-2013/09/B/NZ2/02366 to A.W.

Abbreviations: EHEC, enterohemorrhagic Escherichia coli; HC, hemolytic colitis; HUS, hemolytic-uremic syndrome; m.o.i., multiplicity of infection; ORF, open reading frame; $p$, promoter; $\mathrm{PFU}$ plaque-forming unit; RT-qPCR, Reverse Transcription Quantitative Polymerase Chain Reaction; STEC, Shiga toxin-producing Escherichia coli; Stx phages, Shiga toxin-converting bacteriophages

\section{INTRODUCTION}

Bacteriophages, also known as phages, are bacterial viruses that exist in the environment as free biological molecules. They are found in every environment (e.g. water, air, soil or waste water) and are considered the most abundant organisms on Earth (Clokie et al., 2011; Weitz et al., 2012). Interestingly, these bacterial killers, due to their specificity, have many potential applications not only in the fields of genetic and molecular biology (Węgrzyn \& Węgrzyn, 2005; Kirsch \& Comeau, 2008;
Kutter and et al., 2015), but also in such areas as human therapy (Górski et al., 2018), veterinary (Squires, 2018), agriculture or food and industry control (Gutierrez et al., 2016; Svircev et al., 2018; Zachary et al., 2018). However, bacteriophages also have "the dark side". It is widely known that many bacterial virulence factors are encoded within phage genomes. Moreover, these viruses are classified as mobile genetic elements and for this reason they can play crucial roles in the evolution of microorganisms and creation of pathogenic profiles of many feared bacterial strains (Tinsley et al., 2006; Navarro and Muniesa, 2017). Such bacteria can be exemplified by Shiga toxinproducing Escherichia coli (STEC), with the most dangerous subset of these strains called enterohemorrhagic E. coli (EHEC) (Hunt, 2010). This group is exemplified by the highly pathogenic E. coli O157:H7 strains, and a new atypical E. coli O104:H4 serotype that caused the largest outbreak in Germany and worldwide in 2011, with 54 fatal cases (Bloch et al., 2011).

All STEC strains had acquired the stx genes (stx1 and/or stx2), coding for Shiga toxins, by lysogenization with lambdoid bacteriophages, called Shiga toxinconverting bacteriophages (Stx phages), and which occur in these bacteria as prophages (Allison, 2007; Loś et al., 2011). Their lifecycle and genome organization are similar to those of phage $\lambda$, which is considered as a model organism in microbiology and molecular biology. A characteristic feature of $\lambda$ and Stx phages is their capability to choose one of two alternative pathways of development, lytic or lysogenic, upon infection of the host cell. It is worth to mention that the decision whether to propagate lytically or to lysogenize $E$. coli depends on the environmental factors (temperature, nutrients' availability and multiplicity of infection) and the physiology of bacteria (Ptashne, 2004; Węgrzyn \& Wegrzyn, 2005; Wegrzyn et al., 2012). During lysogenic development, which is one of the replication strategies, phage DNA is incorporated into the host chromosome, forming a prophage. At this stage, the viral genome is replicated together with the bacterial DNA, the majority of phage genes are silenced and no new virions are formed. At the molecular level, this is due to repression of the early lytic promoters, $p_{\mathrm{R}}$ and $p_{\mathrm{L}}$, by the cI protein (Wegrzyn et al., 2012). However, the lysogenic stage is not permanent because when the host cell is endangered by stress conditions the phage developmental switch to the lytic cycle is observed. In this process, virus DNA is excised from the bacterial chromosome and is replicated separately. This leads to synthesis of phage-encoded regulatory and structural proteins, and as a consequence, an assembly of virions is achieved. The lytic development implies the 
death of bacterial cells which allows phage progeny output (Węgrzyn et al., 2012).

The switch from lysogenic to lytic lifecycle is achieved by prophage induction. This process usually takes place when a bacterial cell is stimulated to express genes of the RecA-dependent S.O.S. regulon. In many cases, one common signal that induces lambdoid prophages is bacterial DNA damage, generated by many different factors, such as low $\mathrm{pH}$, the iron ions, UV irradiation, antibiotics and hydrogen peroxide. Under such conditions, the RecA protein recognizes bacterial single-stranded DNA fragments and is activated to stimulate the self-cleavage of the cI repressor. This leads to initiation of phage lytic cycle through transcription from the early $p_{\mathrm{L}}$ and $p_{\mathrm{R}}$ promoters (Loś et al., 2009; Węrzyn et al., 2012; Szych et al., 2013; Licznerska et al., 2016a).

As the stx genes are located in the "late" region of phage genome, downstream of the $p_{\mathrm{R}}$, promoter, their expression occurs only after prophage induction and during the lytic development. Effective expression of the stx genes leads to synthesis of a large amount of Shiga toxins that are released to the human intestine, where they attack eukaryotic cells and block protein synthesis, leading to cell death (Law, 2000; Herold et al., 2005).

The primary symptom of infections of humans by STEC is hemorrhagic colitis (HC). In some cases, especially in children and elderly persons, it may result in various complications, including the hemolytic-uremic syndrome (HUS) with the most common symptoms such as the renal failure, anemia and thrombocytopenia. The mortality rate among patients with HUS is about $10 \%$, but can be even higher, especially without treatment (Razzaq, 2006; Gyles, 2007).

For clinicians, one of the most frustrating aspects of managing STEC infection has been a lack of known effective treatment strategies that diminish the risk of HUS progression. Treatment of infection caused by STEC bacteria is also difficult because many drugs are prophage inducers which enhance expression of the toxin genes and thus enhance severity of the disease symptoms (Kimmitt et al., 2000; Gamage et al. 2004; Seran \& Boedeker, 2008). In vitro analyses show that some anti- bacterial agents, such as quinolones and trimethoprim, dramatically increase both, the bacteriophage burst size and Shiga toxin production in certain STEC strains, and these observations have been confirmed in a murine model (Zhang et al., 2000). Moreover, clinical studies have indicated that antibiotics are not effective in reducing the duration of STEC infection or bloody diarrhea. Therefore, the role of antibiotics for the management of STEC infections still remains undecided after decades of debate and conflicting viewpoints in the literature. Due to serious doubts of using antibiotics, there is an urgent need to develop new drugs for treatment of STEC-infected patients. Proteins crucial for phage development seem to be good molecular targets for such a drug's action.

In the light of the facts described above, it is obvious that detailed understanding of phage gene expression regulation during development of lambdoid viruses is crucial for both, the basic knowledge about the pathogenicity of STEC bacteria and putative further work on treatment of infections caused by these pathogens.

Region of lambdoid phage DNA between the exo and $x$ is genes, which is located in the central part of the genome (called the exo-xis region), is transcribed from the an early $p_{\mathrm{L}}$ promoter, active during the lytic cycle of lambdoid phages and switched off by cI protein during prophage maintenance. In case of phage $\lambda$, the exo-xis region consists of two recognized genes: ea22 and ea8.5, open reading frame $55(\mathrm{ORF})$ and four highly conserved ORFs, named: orf60a, orf63, orf61 and orf73 (Figure 1), whose functions are not yet clear. Comparatively, the exo-xis region of phage $\Phi 24_{B}$, a representative of the Stx phages, contains additional ORFs, but there is no homolog of the ea8.5 gene which encodes the $\lambda$ Ea8.5 protein (Fig. 1).

First speculations that the exo-xis region is involved in regulation at the stage of the phage decision whether to lysogenize the host cell or to enter into the lytic development, appeared in 2002. Sergueev and co-workers demonstrated that expression of some genes and ORFs, located between exo and xis on a defective prophage, causes inhibition of host DNA replication and help the

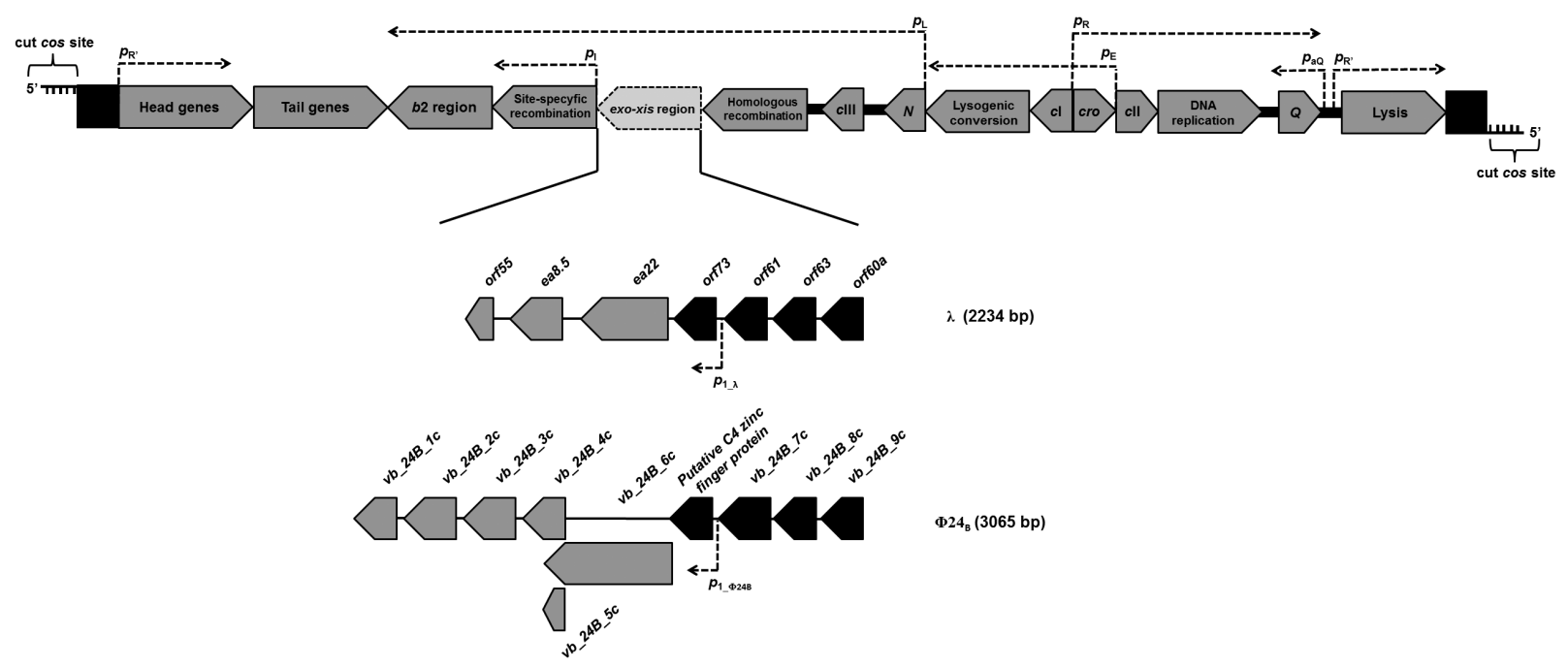

Figure 1. Location and composition of the exo-xis region of the lambdoid viruses: $\lambda$ and $\Phi 24_{B}$.

Black arrows represent four open reading frames: orf60a, orf63, orf61 and orf73 that are highly conserved in the genomes of the tested viruses ( $\geq 97 \%$ nucleotide sequence identity). Genes and ORFs with lower nucleotide identity or additional ORFs that occur in the exo-xis region of phage $\Phi 24_{B}$ are marked by gray arrows. Directionality of transcription from promoters is indicated as thick, punctuated, dashed arrows. Localization of promoters predicted with BPROM: $p_{1 \_\lambda}$ and $p_{1_{\_} \Phi 24 \mathrm{~B}}$ is exactly the same in the case of $\lambda$ and $\Phi 24_{B}$ bacteriophages (Bloch et al., 2014). 
virus to maximize its DNA replication during lytic development (Sergueev et al., 2002). However, no experimental data supporting such a hypothesis were published until 2008. In that year, the first results presenting evidence for the relation between the exo-xis region and phage development were shown (Loś et al., 2008a). These data indicated that overexpression of the exo-xis region impairs the lysogenization process and contributes to a decreased transcription from the cII-stimulated promoters $p_{\mathrm{I}}, p \mathrm{a}_{\mathrm{Q}}$ and $p_{\mathrm{E}}$, which are responsible for promotion of the lysogenic cycle (Loś et al., 2008a). Moreover, a few years later it was demonstrated that more efficient induction of $\lambda$ and $\Phi 24_{B}$ prophages, induced by mitomycin $C$ and hydrogen peroxide, occurred in cultures of host cells bearing a plasmid with the exo-xis region (Bloch et al., 2013). Following prophage induction, an increase in the phage DNA amount was significantly higher in lysogenic E. coli cells containing plasmid-borne exo-xis region, while survival rate of such bacteria was lower (Bloch et al., 2013 and Bloch et al., 2014). These observations were supported by a finding that deletion of the phage exoxis region resulted in a dramatic decrease in the level of phage gene expression that are crucial for the lytic development of lambdoid viruses (Licznerska et al., 2016b).

In order to explain the role of individual genes or ORFs from the exo-xis region involved in the regulation of the lysis-vs.-lysogenization decision, Kwan and others (Kwan et al., 2013) reported that Ea8.5 contains a fused homeodomain/zinc finger fold, which suggests a regulatory role of this protein. Interestingly, overexpression of the ea8.5 gene was responsible for the fuzzy plaque phenotype of the $\lambda c \mathrm{I} b 2$ phage, rapid virus development after prophage induction and repression of the cII-dependent promoters $\left(p_{\mathrm{I}}, p_{\mathrm{aQ}}, p_{\mathrm{E}}\right.$ ) (Loś et al., 2008a; Bloch et al., 2014). On the other hand, expression of orf60a, orf63 and orf61 promotes the lytic pathway of lambdoid phage development (Dydecka et al., 2017 and Dydecka et al., 2018). Mutant phages with deletions of orf $60 \mathrm{a}$ and orf61 influenced the lysis- $\nu s$-lysogenization decision, and impaired prophage induction provoked by different agents, such as mitomycin $\mathrm{C}$ and hydrogen peroxide. Moreover, during the induction process, the efficiency of lytic development of the tested mutants was lower relative to the control variants. What is important, the effects of the orf60a and orf61 deletions were more spectacular for phage $\Phi 24_{\mathrm{B}}$ than for phage $\lambda$ (Dydecka et al., 2018). Similar results were obtained for lambdoid phages with deletion of orf63. Dydecka and others (Dydecka et al., 2017) demonstrated that Orf63 is a small-size, functional protein (63 aa.) with two alpha helices, likely intertwined to form an oligomer. Functionally, the Orf63 protein probably participates in regulation of expression of crucial phage genes and ORFs from the exo-xis region during prophage induction. Moreover, lack of sequences of orf 63 in the genomes of $\lambda$ and $\Phi 24_{B}$ resulted in the delay in phage development after prophage induction and increased survival of the host cells during lytic cycle (Dydecka et al., 2017).

In this study, we have concentrated on the physiological role of orf73 in regulation of the lambdoid phage development.

\section{MATERIALS AND METHODS}

Bacteria, bacteriophages and growth conditions. All Escherichia coli strains and lambdoid viruses used in this study are presented in Table 1. Bacterial cells were routinely cultured in the Luria-Bertani (LB) liquid medium at $30^{\circ} \mathrm{C}$ under aerobic conditions. The same broth, supplemented with $0.7 \%$ or $1.5 \%$ bacteriological agar, was used as a top or bottom agar, respectively. Bacteriophage suspensions were stored in TM buffer $(10 \mathrm{mM}$ Tris- $\mathrm{HCl}, 10 \mathrm{mM} \mathrm{MgSO}_{4}, \mathrm{pH} \mathrm{7.2)}$ at $4^{\circ} \mathrm{C}$. The phage titration procedure was performed by using the standard double overlay method with some modifications. Briefly, $1 \mathrm{ml}$ of the indicator E. coli MG1655 strain was mixed with $2 \mathrm{ml}$ of top agar supplemented with $\mathrm{MgSO}_{4}$ $\left(\lambda\right.$ and $\lambda \Delta$ orf 73 phages) or $\mathrm{MgSO}_{4}$ and $\mathrm{CaCl}_{2}\left(\Phi 24_{\mathrm{B}}\right.$ and $\Phi 24_{\mathrm{B}} \Delta$ orf 73 phages), to a final concentration of $10 \mathrm{mM}$ of each. The mixtures were poured onto Petri plates filled with bottom agar or bottom agar with sublethal concentration of chloramphenicol $(2.5 \mu \mathrm{g} / \mathrm{ml})$, according to a procedure described by Loś and others (Loś et al., 2008b). Supplementation of top agar with appropriate antibiotic was used to obtain visible plaques formed on a bacterial lawn by Stx phages. Afterwards, $2.5 \mu \mathrm{l}$ of each serial dilution of phage lysate was spotted onto double-agar plate and incubated at $37^{\circ} \mathrm{C}$ for $16 \mathrm{~h}$. Next day, plaques were counted and the $\mathrm{PFU} / \mathrm{ml}$ value was calculated.

Bioinformatics analysis. Multiple sequence alignment of the nucleotide and amino acid sequences of orf 73 from $\lambda$ phage (NC_001416) and Stx phages: $\Phi 24_{\mathrm{B}}$ phage (HM208303), 933W phage (NC_000924), VT2 Sakai phage (AP000422), Stx1 converting phage (NC_004913) and Stx2 converting phage II (NC_004914), was per-

Table 1. Escherichia coli strains and bacteriophages used in this work.

\begin{tabular}{|c|c|c|}
\hline Bacterial strains or bacteriophages & Relevant genotype or description & References \\
\hline \multicolumn{3}{|l|}{ E. coli strains } \\
\hline MG1655 & $\mathrm{F}-\lambda-i l v G r f b-50 r p h-1$ & Jensen, 1993 \\
\hline MG1655 $(\lambda)$ & MG1655 bearing $\lambda$ prophage & Bloch et al., 2013 \\
\hline MG1655 ( $\lambda \Delta$ orf73) & MG1655 bearing $\lambda$ prophage with deletion of orf73 & Licznerska et al., 2016b \\
\hline MG1655 (Ф24 $)$ & MG1655 bearing $\Phi 24_{B}$ prophage & Bloch et al., 2013 \\
\hline MG1655 (Ф24 $\left.{ }_{B} \Delta o r f 73\right)$ & MG1655 bearing $\Phi 24_{B}$ prophage with deletion of orf73 & Licznerska et al., 2016b \\
\hline \multicolumn{3}{|l|}{ Bacteriophages } \\
\hline$\lambda$ & carries a frameshift mutation relative to Ur-lambda & Hendrix and Duda, 1992 \\
\hline$\lambda \Delta o r f 73$ & $\lambda$ phage with deletion of orf73 & Licznerska et al., 2016b \\
\hline$\Phi 24_{\text {в }}$ & $\Phi 24_{B} \Delta s t \times 2:: c a t$ & Allison, 2003 \\
\hline$\Phi 24_{B} \Delta o r f 73$ & $\Phi 24_{B}$ phage with deletion of orf 73 & Licznerska et al., 2016b \\
\hline
\end{tabular}


formed by using the ClustalW algorithm (https://www. genome.jp/tools-bin/clustalw).

Monitoring of phage lytic development during one round of infection of the $E$. coli host cells. Lytic cycle of the tested bacteriophages was studied in one-step growth experiments, according to the procedure described by Bloch and others (Bloch et al., 2013). Host bacteria were grown in the $\mathrm{LB}$ medium at $30^{\circ} \mathrm{C}$ to $A_{600}=0.2$. Samples $(10 \mathrm{ml})$ were centrifuged $(2000 \times g$ for $10 \mathrm{~min}$ at $\left.4^{\circ} \mathrm{C}\right)$, the supernatant was discarded and the bacterial pellet was suspended in 1/10 of the initial volume of LB medium supplemented with appropriate ions and $3 \mathrm{mM}$ sodium azide. After 5 -min incubation of the sample at $30^{\circ} \mathrm{C}$, the phage particles were added to bacteria to m.o.i. $=0.05$. Phage adsorption was carried out at $30^{\circ} \mathrm{C}$ for $10 \mathrm{~min}$. Then, the mixture was diluted tenfold in LB medium with $3 \mathrm{mM}$ sodium azide and centrifuged $\left(2000 \times g\right.$ for $10 \mathrm{~min}$ at $\left.4^{\circ} \mathrm{C}\right)$. To remove unadsorbed virions, the centrifugation procedure was repeated three times. In the next step, the suspension was diluted 1000fold in $\mathrm{LB}$ medium pre-warmed to $30^{\circ} \mathrm{C}$, supplemented with $3 \mathrm{mM}$ sodium azide and aerated with shaking at the same temperature. The number of infective centers was estimated in the interval of $0-15$ min after dilution by plating under permissive conditions. Samples taken at later times were cleared by vigorously shaking for 1 min with chloroform. Following the centrifugation step $\left(2000 \times g\right.$ for $5 \mathrm{~min}$ at $\left.4^{\circ} \mathrm{C}\right)$, the number of phage progeny was estimated by plating on indicator E. coli MG1655 strain. Plates were incubated at $37^{\circ} \mathrm{C}$ overnight and then the burst size was calculated as a ratio of PFU/ml of the tested samples to the $\mathrm{PFU} / \mathrm{ml}$ of infection centers.

Survival test of host bacteria after phage infection. To determine the survival rate of $E$. coli bacteria after phage infection, a previously published method was used (Dydecka et al., 2017). Bacterial cells were grown in LB liquid medium at $30^{\circ} \mathrm{C}$ to $\mathrm{A}_{600}=0.2$. Samples $(4 \mathrm{ml})$ were withdrawn and centrifuged $\left(2000 \times g\right.$ for $10 \mathrm{~min}$ at $\left.4{ }^{\circ} \mathrm{C}\right)$. The obtained pellets were suspended in $1.2 \mathrm{ml}$ of LB medium supplemented with appropriate ions. In the next step, the phage lysate was added to the samples to m.o.i. of 1,5 , or 10 , and following incubation at $30^{\circ} \mathrm{C}$, serial dilutions in $0.85 \%$ sodium chloride were prepared. Afterwards, $40 \mu \mathrm{l}$ of each dilution were plated onto bottom agar and incubated at $37^{\circ} \mathrm{C}$ overnight. The fraction of surviving bacteria was calculated in relation to the control variants treated with TM buffer $(10 \mathrm{mM}$ Tris- $\mathrm{HCl}$, $10 \mathrm{mM} \mathrm{MgSO}, \mathrm{pH} 7.2$ ) instead of the phage lysate.

Lysogenization test of bacterial cells after phage infection. To estimate the percentage of lysogenic bacteria after bacteriophage infection, a procedure presented previously was used (Dydecka et al., 2017). Host bacteria were cultivated in $\mathrm{LB}$ liquid medium at $30^{\circ} \mathrm{C}$ to $\mathrm{A}_{600}=0.2$. Aliquots of these cultures were centrifuged $(2000 \times \mathrm{g}$ for $10 \mathrm{~min}$ at $4{ }^{\circ} \mathrm{C}$ ) and the pellets were washed twice with the TCM buffer $(10 \mathrm{mM}$ Tris- $\mathrm{HCl} \mathrm{pH} 7.2,10 \mathrm{mM}$ $\mathrm{MgSO}_{4}, 10 \mathrm{mM} \mathrm{CaCl}$ ). In the next step, phage suspensions were added to bacterial samples to m.o.i. $=1,5$ or 10. Following incubation of the mixtures at $30^{\circ} \mathrm{C}$, serial dilutions were prepared and $20 \mu \mathrm{l}$ of each was spread on $\mathrm{LB}$ agar plates. After overnight incubation at $37^{\circ} \mathrm{C}$, the obtained bacterial colonies were passaged in each well of a 96-well plate filled with LB medium. The putative lysogens were shaken at $37^{\circ} \mathrm{C}$ to $\mathrm{A}_{600}=0.1$. Then, the bacterial cultures were treated with ultraviolet radiation at 50 $\mathrm{J} / \mathrm{m}^{2}$ for $20 \mathrm{~s}$ and incubated for $2 \mathrm{~h}$ at $37^{\circ} \mathrm{C}$. After the induction process, the putative lysogens were mixed with chloroform and centrifuged $\left(2000 \times g\right.$ for $10 \mathrm{~min}$ at $\left.4^{\circ} \mathrm{C}\right)$. The water phase was spotted onto a double-layer LB agar. After overnight incubation at $37^{\circ} \mathrm{C}$, the percentage of lysogens among survivors was determined and presented as a ratio of number of lysogens to all tested bacterial colonies.

The rate of adsorption of virions on the host cells. The efficiency of phage adsorption process was measured according to the procedure described previously, with some modifications (Bloch et al., 2013). Bacteria were grown in $\mathrm{LB}$ liquid medium at $30^{\circ} \mathrm{C}$ to $\mathrm{A}_{600}=0.1$. Samples $(1 \mathrm{ml})$ were centrifuged $(2000 \times g$ for $10 \mathrm{~min}$ at $4^{\circ} \mathrm{C}$ ) and the pellets were washed twice with $0.85 \%$ sodium chloride. Finally, the pellets were suspended in 0.15 $\mathrm{ml}$ of LB medium supplemented with appropriate ions. Tested bacteriophages were added to the bacterial samples to m.o.i. $=0.1$. During incubation at $30^{\circ} \mathrm{C}$, the phage titers were determined at specified times by using the double-layer LB agar method. Plates were incubated at $37^{\circ} \mathrm{C}$ for $16 \mathrm{~h}$. Samples withdrawn immediately after addition of phage particles to the host cells (time 0) were considered as $100 \%$ of non-adsorbed viruses and other values were calculated relative to them.

Statistical methods. Each experiment was prepared in three independent, biological replicates. The variation among replicates was presented as error bars indicating standard deviation (S.D.). The significance of differences between mean values of two measured parameters was assessed by using $t$-test. Differences were considered significant when $p<0.05$ or $p<0.01$, and are marked on the figures by one or two asterisks, respectively.

\section{RESULTS}

\section{The nucleotide sequences of orf73 and amino acid sequences of its putative products are conserved among the family of lambdoid viruses}

The orf73 locus is placed between orf61 and the ea22 gene in the genome of $\lambda$ and $\Phi 24_{B}$ viruses. According to available data, this ORF remains under control of the early $p_{\mathrm{L}}$ and BPROM-predicted $p_{1}$ promoters (Fig. 1) (Bloch et al., 2014). As we demonstrated in Table 2, the nucleotide sequence of orf73 is highly conserved among the group of lambdoid viruses, with the scores of similarities $\geq 97 \%$. Moreover, we have also tested the identity

Table 2. Scores of pairwise alignments of the nucleotide sequences of orf73 from the $\lambda$ phage (NC_001416) and Stx phages: Ф24 B phage (HM208303), 933W phage (NC_000924), VT2 Sakai phage (AP000422), Stx1 converting phage (NC_004913) and Stx2 converting phage II (NC_004914).

The multiple sequence alignment was performed by using the ClustalW algorithm. Pairwise scores represent the percentage identity between two sequences, taking into account length of the alignment.

\begin{tabular}{|c|c|c|c|c|c|c|}
\hline & $\lambda$ & $\Phi 24_{B}$ & $933 W$ & VT2 Sakai & Stx1 & Stx2_II \\
\hline$\lambda$ & & 97 & 97 & 97 & 97 & 97 \\
\hline$\Phi 24_{B}$ & & & 99 & 99 & 99 & 99 \\
\hline $933 W$ & & & & 100 & 100 & 100 \\
\hline VT2 Sakai & & & & & 100 & 100 \\
\hline Stx1 & & & & & & 100 \\
\hline Stx2_II & & & & & & \\
\hline
\end{tabular}


Table 3. Scores of pairwise alignments of the predicted amino acid sequences of Orf73 from the $\lambda$ phage (NC_001416) and Stx phages: $\$ 24_{\text {e }}$ phage (HM208303), 933W phage (NC 000924), VT2 Sakai phage (AP000422), Stx1 converting phage (NC_004913) and Stx2 converting phage II (NC_004914).

The multiple sequence alignment was performed by using the ClustalW algorithm. Pairwise scores represent the percentage identity between two sequences, taking into account length of the alignment.

\begin{tabular}{|c|c|c|c|c|c|c|}
\hline & $\lambda$ & $\Phi 24_{\text {в }}$ & $933 \mathrm{~W}$ & VT2 Sakai & Stx 1 & Stx2_II \\
\hline$\lambda$ & & 97 & 97 & 97 & 97 & 97 \\
\hline$\Phi 24_{\text {B }}$ & & & 100 & 100 & 100 & 100 \\
\hline $933 W$ & & & & 100 & 100 & 100 \\
\hline VT2 Sakai & & & & & 100 & 100 \\
\hline Stx1 & & & & & & 100 \\
\hline
\end{tabular}

Stx2_II

of the predicted amino acids sequences of the putative products of orf 73 . As we present in Table 3, the high level of similarity is kept at the protein level of Orf73 for all tested $\lambda$ and Stx phages $(\geq 97 \%)$. Taking into account the results of these comparisons, we suppose that orf73 can be a true gene that encodes a real protein product.

\section{Deletion of orf73 influences phage infection and host survival}

Previous studies indicated that either overexpression or deletion of the whole exo-xis region or particular genes and ORFs affect the lytic cycle of lambdoid bacteriophages after infection of E. coli bacteria under standard laboratory conditions (Loś et al., 2008a; Bloch et al., 2013 and Bloch et al., 2014; Licznerska et al., 2016b; Dydecka et al., 2017 and Dydecka et al., 2018). Here, we demonstrate that in one-step growth experiment both lambdoid bacteriophages with the deletion of orf73 present shorter latent period and more efficient intracellular lytic development relative to the wild-type viruses (Fig. 2). Interestingly, the latent period of wild-

A.

$\square \mathrm{MG} 1655+\Lambda \quad \mathrm{MG} 1655+\lambda \Delta \mathrm{Or} 73$

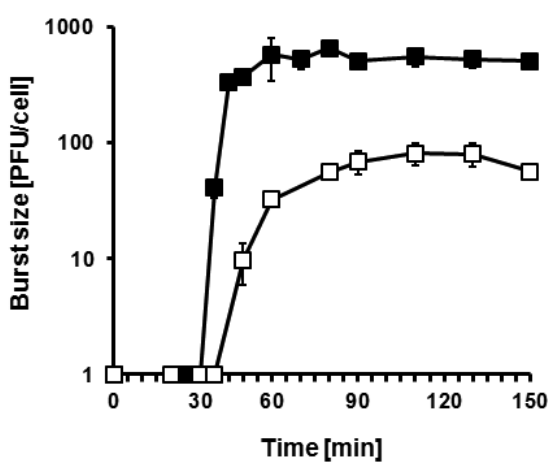

type $\lambda$ phage was about 5 min longer relative to the $\lambda$ deletion mutant (Fig. 2, panel A), while in the case of phage $\Phi 24_{B}$ the first phage progeny appeared about 50 minutes later in comparison to $\Phi 24_{\mathrm{B}}$ with deletion of the orf73 homolog (Fig. 2, panel B). Moreover, the average burst size values of $\lambda(68 \pm 15 \mathrm{PFU} /$ cell $)$ and $\Phi 24_{\mathrm{B}}$ (25 $\pm 7 \mathrm{PFU} /$ cell) were several times lower relative to their deletion mutants, $\lambda \Delta$ orf 73 (500 PFU/cell \pm 60$)$ and

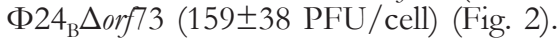

We also found that the survival rates of bacterial cells in the population infected with $\lambda$ and $\Phi 24_{B}$ phages devoid of orf 73 were lower than those in experiments with wild-type lambdoid viruses under all tested m.o.i. conditions (Fig. 3). In accordance with the host survival experiments, we have also observed that efficiency of lysogenization was less effective in the absence of orf 73 at m.o.i. $=5$ and 10 (Fig. 4). Moreover, the differences between mutants and wild-type phages observed during the analyzed processes did not depend on adsorption of viruses on the surface of bacterial cells. We demonstrated that no significant effects of orf 73 deletion on this parameter could be found for the $\lambda$ and Stx phages (Fig. 5).

All of these observations allowed us to propose that orf73 can play an important role in phage development, particularly at the stage of the lysis- $\nu$ s.-lysogenization decision.

\section{DISCUSSION}

Although principles of the mechanism of phage development regulation have been broadly described for cells lysogenized with bacteriophage $\lambda$ (Ptashne 2004; Węgrzyn \& Węgrzyn, 2005; Węgrzyn et al., 2012), and despite recent reports providing information about this regulation in the Stx phages (Murphy et al., 2008; Loś et al., 2012; Riley et al., 2012), it appears that our knowledge about this process is still far from completeness. There is evidence that genes and ORFs from the exo-xis region of lambdoid viruses can be involved in the lysisvs.-lysogenization decision (Loś et al., 2008a; Bloch et al., 2013 and Bloch et al., 2014; Licznerska et al., 2016b, Dydecka et al., 2017 and Dydecka et al., 2018). Moreover, many bioinformatics and transcriptomic approaches (e.g. microarray or RNA-Seq analyses) have indicated a growing number of genes encoding small proteins (20130 amino acids) that can play a variety of roles in the

B.

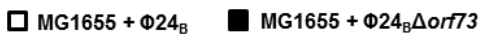

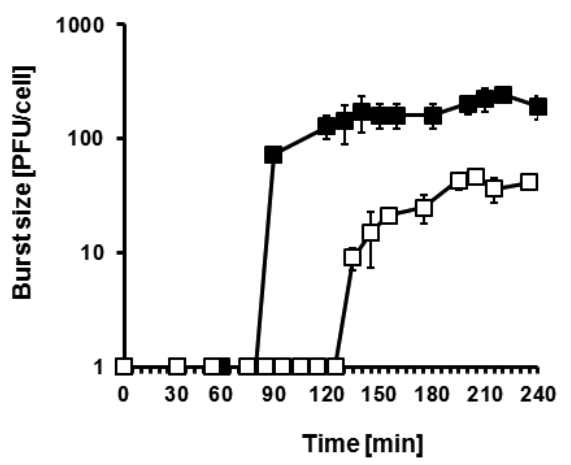

Figure 2. The intracellular development of $\lambda$ (panel $A$, white squares), $\$ 24_{B}$ (panel $B$, white squares) and their recombinant mutants with deletion of orf73 (panels A and B; black squares) following phage infection of the $E$. coli MG1655 host.

The presented results are mean values from three independent, biological experiments with error bars indicating S.D. 
A.

$\square \mathrm{MG} 1655+\lambda$

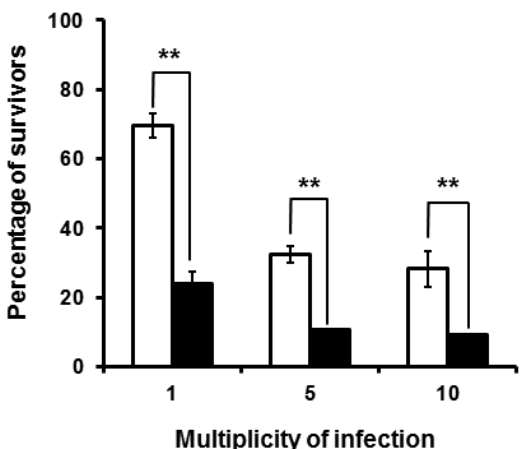

B.

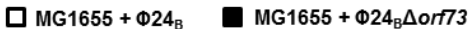

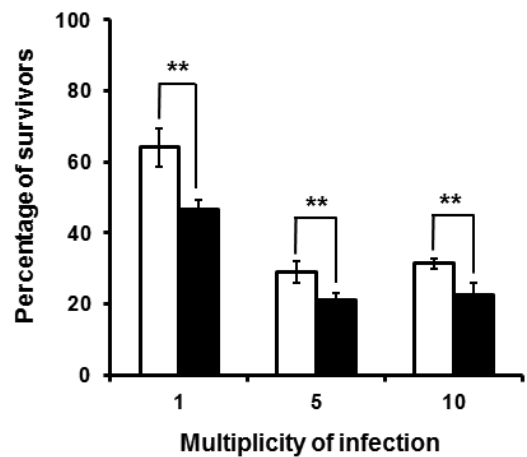

Figure 3. Effects of orf73 deletion on survival of the host cells after infection with wild-type bacteriophages: $\lambda$ (panel $A$, white columns) and $\Phi 24_{B}$ (panel B, white columns) or their recombinant mutants (panels $A$ and B; black columns).

Results are presented as mean values \pm S.D. from three independent, biological experiments. A $t$-test was performed for results obtained at each m.o.i. The significance of differences between fractions of bacterial cells infected with wild-type phages and their deletion mutants is marked by asterisks, $p<0.01\left(^{* *}\right)$.

A.

$\square \mathrm{MG} 1655+\lambda$

MG1655 + $\Delta \Delta O \mathrm{Or}_{73}$

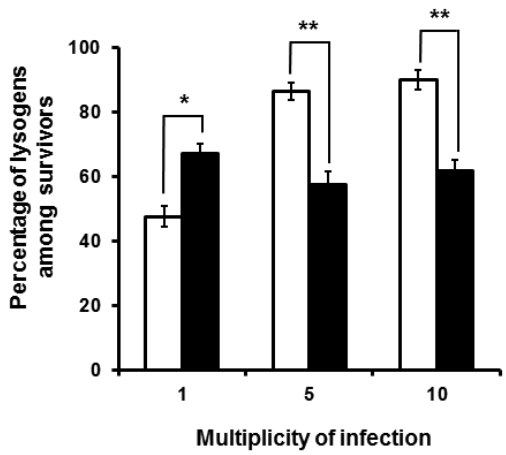

B.

$\square \mathrm{MG1655}+\Phi 24_{\mathrm{B}} \quad \square \mathrm{MG1655}+\Phi 24_{\mathrm{B}} \Delta \mathrm{Or} 73$

Figure 4. Effects of orf73 deletion on lysogenization of $E$. coli cells with wild-type bacteriophages: $\lambda$ (panel $A$, white columns) and $\Phi 24_{\text {B }}$ (panel B, white columns) or their recombinant mutants (panels A and B; black columns).

Results are presented as mean values from three independent, biological experiments with S.D. indicated by error bars. A t-test was performed for results obtained at each m.o.i. Statistically significant differences between wild-type bacteriophages and their deletion mutants are marked by asterisks, $p<0.05\left(^{*}\right)$ or $p<0.01\left(^{* *}\right)$.

A.

MG1655 + ^

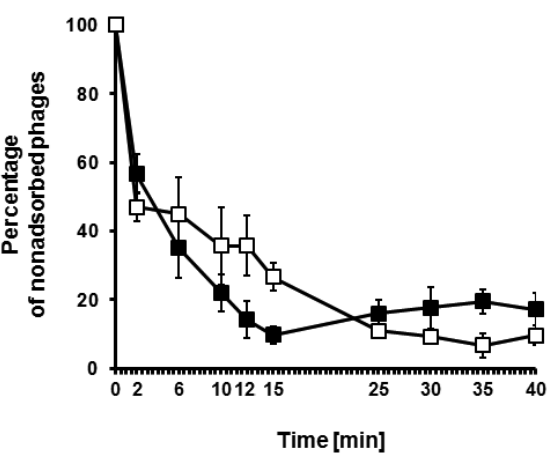

B.

$\square$ MG1655 + Ф24 $\quad \square$ MG1655 + $\$ 24_{\mathrm{B}} \Delta \mathrm{O}+73$

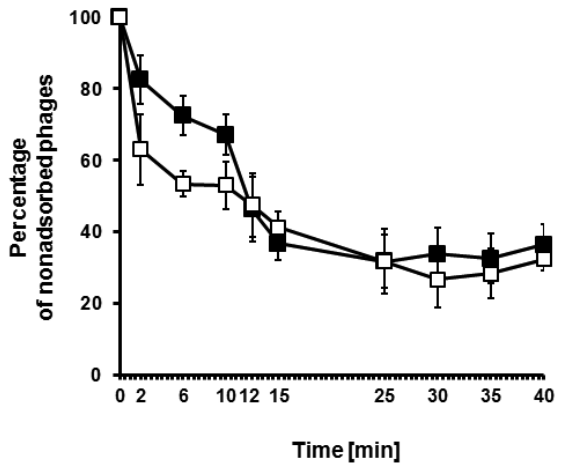

Figure 5. Rate of adsorption of lambdoid bacteriophages: $\lambda$ (panel $A$, white squares) and $\Phi 24_{B}$ (panel $B$, white squares) or their recombinant mutants (panels A and B; black squares) to the E. coli MG1655 host at m.o.i. of 0.1.

The presented results are mean values from three independent, biological experiments with error bars indicating S.D. 
world of microorganisms (Hemm et al., 2008; Ibrahim et al., 2007; Hobbs et al., 2011). Keeping these reports in mind, we would like to pay attention to the physiological role of orf73 during infection process of $E$. coli with the $\lambda$ and $\Phi 24_{\mathrm{B}}$ phages.

The sequence of orf 73 is located between orf61 and ea22 in the $\lambda$ genome and it is also highly conserved among the Stx phages: $\Phi 24_{B}$, 933W, VT2 Sakai, Stx1 and Stx2_II (Fig. 1 and Table 2). Our results from RTqPCR analyses, as well as expression patterns of $\lambda$ genome from ribosome profiling, show increased expression of orf 73 during phage $\lambda$ development. Presence of the orf73-derived transcript was also confirmed by RTqPCR during lifecycle of phage $\Phi 24_{\mathrm{B}}$ (Liu et al., 2013; Bloch et al., 2014). It is important to note that the level of orf73 expression during infection or prophage induction in E. coli was comparable to that of the ea22 gene. Moreover, orf73 and ea22 were expressed at significantly higher levels than the rest of the exo-xis region during $\Phi 24_{B}$ prophage induction in cells treated with hydrogen peroxide. Interestingly, in silico analysis also predicted the existence of a newly detected, strong $p_{1 \_} \lambda / \$ 24 \mathrm{~B}$ promoter between orf61 and orf73. This $p_{1}$ promoter, together with early $p_{\mathrm{L}}$ promoter, might control and enhance the expression of ea22 and orf73 (Fig. 1) (Bloch et al., 2014). Therefore, it seems that the mechanisms of action and regulation of orf73 and ea22 can be similar.

Such observations allow us to suppose that orf 73 might be translated into an active polypeptide product and plays an important role in regulation of the lambdoid bacteriophage development, especially at the stage of the lysis- $\nu s$.-lysogenization decision. This hypothesis can be corroborated by the fact that the potential product of orf73 contains a zinc finger fold. Such a structure, partially resembling those occurring in eukaryotic proteins involved in regulation of the tissue and organ development, may potentially interact with both, the nucleic acids and other proteins (Berg, 1990). Importantly, this domain is also characteristic for the $\lambda$ Ea8.5 regulatory protein that probably interacts with bacterial proteins, including DnaA, DiaA or Had, and can also regulate transcription at the cII-dependent promoters which are involved in the lysis- $\nu$ s.-lysogenization decision (Loś et al., 2008a; Kwan et al., 2013).

In the light of results presented in this paper, we conclude that expression of orf 73 promotes the lysogenic pathway of the lambdoid bacteriophages' development. We observed that the mutant phages with deletions of orf73 revealed lower efficiency of lysogenization of the host cells and higher level of burst size during the lytic cycle. Survival rates of E. coli bacteria in the population infected with deletion mutants were lower relative to the wild-type lambdoid phages. Moreover, the decision to propagate lytically did not depend on environmental factors, such as nutrients availability and multiplicity of infection.

Taking the above summarized results into consideration, we suggest that orf73 is important, but not essential, in regulation of the lambdoid bacteriophage development. In contrast to orf60a, orf63 and orf 61 , expression of orf73 favors not the lytic, but the lysogenic cycle of the $\lambda$ and Stx phages. However, the molecular mechanism of action of orf 73 still remains unclear. In addition, it seems that the products encoded in the exo-xis region strongly cooperate at the stage of the lysis- $\nu$ s.-lysogenization decision.

\section{REFERENCES}

Allison HE, Sergeant MJ, James CE, Saunders JR, Smith DL, Sharp RJ, Marks TS, McCarthy AJ (2003) Immunity profiles of wild-type and recombinant Shiga-like toxin-encoding bacteriophages and characterization of novel double lysogens. Infect Immun 71: 3409-3418. http://doi.org//10.1128/IAI.71.6.3409-3418.2003

Allison HE (2007) Stx-phages: drivers and mediators of the evolution of STEC and STEC-like pathogens. Future Microbiol 2: 165-174. http://doi.org/10.2217/17460913.2.2.165

Berg JM (1990) Zinc finger domains: hypotheses and current knowledge. Ann Revi Biophys 19: 405-421. https://doi. org/10.1146/annurev.bb.19.060190.002201

Bloch S, Nejman-Faleńczyk B, Dydecka A, Loś JM, Felczykowska A, Węgrzyn A, Węgrzyn G (2014) Different expression patterns of genes from the exo-xis region of bacteriophage $\lambda$ and Shiga toxin-converting bacteriophage $\Phi 24_{\mathrm{B}}$ following infection or prophage induction in Escherichia coli. PLOS ONE 9: e108233. https://doi. org/10.1371/journal.pone.0108233

Bloch S, Nejman-Faleńczyk J, Łoś JM, Barańska S, Lepek K, Felczykowska A, Loś M, Węgrzyn G, Węgrzyn A (2013) Genes from the exo-xis region of $\lambda$ and Shiga toxin-converting bacteriophages influence lysogenization and prophage induction. Arch Microbiol 195: 693-703. https://doi.org/10.1007/s00203-013-0920-8

Bloch S, Felczykowska A, Nejman-Faleńczyk B (2012) Escherichia coli O104:H4 outbreak - have we learnt a lesson from it? Acta Biochim Pol 59: 483-488. https://doi.org/10.18388/abp.2012 2081

Clokie MRJ, Millard AD, Letarov AV, Heaphy S (2011) Phages in nature. Bacteriophage 1: 31-45. https://doi.org/10.4161/bact.1.1.14942

Dydecka A, Bloch S, Rizvi A, Perez S, Nejman-Faleńczyk B, Topka G, Gąsior T, Necel A, Węgrzyn G, Donaldson LW, Węgrzyn A (2017) Bad phages in good bacteria: Role of the mysterious orf 63 of $\lambda$ and Shiga toxin-converting $\Phi 24_{\mathrm{B}}$ bacteriophages. Front Microbiol 8: 1618. https://doi.org/10.3389/fmicb.2017.01618

Dydecka A, Nejman-Faleńczyk B, Bloch S, Topka G, Necel A, Donaldson LW, Wegrzyn G, Węgrzyn A (2018) Roles of orf60a and orf61 in development of bacteriophages $\lambda$ and $\Phi 24_{\mathrm{B}}$. Viruses 10: E553. https://doi.org/10.3390/v10100553

Gamage SD, Patton AK, Hanson JF, Weiss AA (2004) Diversity and host range of Shiga toxin encoding phage. Infect Immun 72: 71317139. https://doi.org/10.1128/IAI.72.12.7131-7139.2004

Górski A, Międzybrodzki R, Łobocka M, Głowacka-Rutkowska A, Bednarek A, Borysowski J, Jończyk- Matysiak E, ŁusiakSzelachowska M, Weber-Dabrowska B, Bagińska N, Letkiewicz S, Dabrowska K, Scheres J (2018) Phage therapy: what have we learned? Viruses 10: 288. https://doi.org/10.3390/v10060288

Gutiérrez D, Rodríguez-Rubio L, Martínez B, Rodríguez A, García P (2016) Bacteriophages as weapons against bacterial biofilms in the food industry. Front Microbiol 7: 825. https://doi.org/10.3389/ fmicb.2016.00825

Hemm MR, Paul BJ, Schneider TD, Storz G, Rudd KE (2008) Small membrane proteins found by comparative genomics and ribosome binding site models. Mol Microbiol 70: 1487-1501. https://doi. org/10.1111/j.1365-2958.2008.06495.x

Hendrix RW, Duda RL (1993) Bacteriophage lambda PaPa: Not a mother of all lambda phages. Science 258: 1145-1148. https://doi. org//10.1126/science.1439823

Herold S, Siebert J, Huber A, Schmidt H (2005) Global expression of prophage genes in Escherichia coli O157:H7 strain EDL933 in response to norfloxacin. Antimicrob Agents Chemother 49: 931-944. https://doi.org//10.1128/AAC.49.3.931-944.2005

Hobbs EC, Fontaine F, Yin X, Storz G (2011) An expanding universe of small proteins. Curr Opin Microbiol 14: 167-173. https://doi. org/10.1016/j.mib.2011.01.007

Hunt JM (2010) Shiga toxin-producing Escherichia coli (STEC). Clin Lab Med 30: 21-45. https://doi.org/10.1016/j.cll.2009.11.001

Ibrahim M, Nicolas P, Bessieres P, Bolotin A, Monnet V, Gardan R (2007) A genome-wide survey of short coding sequences in Streptococci. Microbiology 153: 3631-3644. https://doi.org/10.1099/ mic.0.2007/006205-0

Jensen KF (1993) The Escherichia coli K-12 wild types W3110 and MG1655 have an $r p h$ frameshift mutation that leads to pyrimidine starvation due to low pyre expression levels. J Bacteriol 175: 34013407. https://doi.org//10.1128/jb.175.11.3401-3407.1993

Kimmitt PT, Harwood CR, Barer MR (2000) Toxin gene expression by Shiga toxin-producing Escherichia coli: the role of antibiotics and the bacterial SOS response. Emerg Infect Dis 6: 458-465. http://dx.doi. org/10.3201/eid0605.000503

Krisch HM, Comeau AM (2008) The immense journey of bacteriophage T4 - from d'Hérelle to Delbrück and then to Darwin and beyond. Res Microbiol 159: 314-324. https://doi.org/10.1016/j. resmic.2008.04.014

Kutter EM, Kuhl SJ, Abedon ST (2015) Re-establishing a place for phage therapy in western medicine. Future Microbiol 10: 685-688. https:// doi.org/10.2217/fmb.15.28 
Kwan JJ, Smirnova E, Khazai S, Evanics F, Maxwell KL, Donaldson LW (2013) The solution structures of two prophage homologues of the bacteriophage $\lambda$ Ea8.5 protein reveal a newly discovered hybrid homeodomain/zinc-finger fold. Biochemistry 52: 3612-3614. https://doi.org/10.1021/bi400543w

Law D (2000) Virulence factors of Escherichia coli O157 and other Shiga toxin-producing E. coli. J Appl Microbiol 88: 729-745. https://doi. org/10.1046/j.1365-2672.2000.01031.x

Licznerska K, Nejman-Falenczyk B, Bloch S, Dydecka A, Topka G, Gąsior T, Węgrzyn A, Węgrzyn G (2016a) Oxidative stress in Shiga toxin production by enterohemorrhagic Escherichia coli. Oxid Med Cell Longev 2016: 3578368. http://dx.doi.org/10.1155/2016/3578368

Licznerska K, Dydecka A, Bloch S, Topka G, Nejman-Faleńczyk B, Wegrzyn A, Wegrzyn G (2016b) The Role of the exo-xis region in oxidative stress-mediated induction of Shiga toxin-converting prophages. Oxid Med Cell Longev 2016: 8453135. http://dx.doi. org/10.1155/2016/8453135

Liu X, Jiang H, Gu Z, Roberts JW (2013) High-resolution view of bacteriophage lambda gene expression by ribosome profiling. Proc Natl Acad Sci 110: 11928-11933. http://doi.org/10.1073/ pnas. 1309739110

Loś JM, Loś M, Węgrzyn A, Węgrzyn G (2008a) Role of the bacteriophage $\lambda$ exo-xis region in the virus development. Folia Microbiol 53: 443-450. http://doi.org/10.1007/s12223-008-0068-0

Loś JM, Golec P, Wegrzyn G, Wegrzyn A, Loś M (2008b) Simple method for plating Escherichia coli bacteriophages forming very small plaques or no plaques under standard conditions. Appl Environ $\mathrm{Mi}$ crobiol 74: 5113-5120, http://doi.org/10.1128/AEM.00306-08.

Łoś JM, Loś M, Węgrzyn G, Węgrzyn A (2009) Differential efficiency of induction of various lambdoid prophages responsible for production of Shiga toxin in response to different induction agents. Microbial Pathogen 47: 289-298. http://dx.doi.org/10.1016/j.micpath.2009.09.006

Łoś JM, Loś M, Węgrzyn G (2011) Bacteriophages carrying Shiga toxin genes: genomic variations, detection and potential treatment of pathogenic bacteria. Future Microbiol 6: 909-924. https://doi. org/ $10.2217 /$ fmb. 11.70

Loś JM, Loś M, Węgrzyn A, Węgrzyn G (2012) Altruism of Shiga toxin-producing Escherichia coli: recent hypothesis versus experimental results. Front Cell Infect Microbiol 2: 166. https://doi.org/10.3389/ fcimb.2012.00166

Moye ZD, Woolston J, Sulakvelidze A (2018) Bacteriophage applications for food production and processing. Viruses 10: 205. https:// doi.org/10.3390/v10040205

Murphy KC, Ritchie JM, Waldor MK, Løbner-Olesen A, Marinus MG (2008) Dam methyltransferase is required for stable lysogeny of the Shiga toxin (Stx2)-encoding bacteriophage 933W of enterohemor- rhagic Escherichia coli O157:H7. J Bacteriol 190: 438-441. http://doi. org/10.1128/JB.01373-07

Navarro F, Muniesa M (2017) Phages in the human body. Front Microbiol 8: 566. https://doi.org/10.3389/fmicb.2017.00566

Ptashne M (2004) A Genetic Switch: Phage Lambda Revisited. 3nd edn. Cold Spring Harbor Laboratory Press ISBN 0879697164

Razzaq S (2006) Hemolytic uremic syndrome: an emerging health risk. Am Family Physician 74: 991-998

Riley LM, Veses-Garcia M, Hillman JD, Handfield M, McCarthy AJ, Allison HE (2012) Identification of genes expressed in cultures of E. coli lysogens carrying the Shiga toxin-encoding prophage $\Phi 24_{B}$. BMC Microbiology 12: 42. http://doi.org/10.1186/1471-2180-12-42

Sergueev K, Court D, Reaves L, Austin S (2002) E. coli cell-cycle regulation by bacteriophage $\lambda$. J Mol Biol 324: 297-307. http://doi. org/10.1016/S0022-2836(02)01037-9

Serna A, Boedeker EC (2008) Pathogenesis and treatment of Shiga toxin-producing Escherichia coli infections. Curr Opin Gastroenterol 24: 38-47. http://doi.org/10.1097/mog.0b013e3282f2dfb8

Squires RA (2018) Bacteriophage therapy for management of bacterial infections in veterinary practice: what was once old is new again. New Zealand Vet J 66: 229-235. https://doi.org/10.1080/00480169 .2018 .1491348

Svircev A, Roach D, Castle A (2018) Framing the future with bacteriophages in agriculture. Viruses 10: E218. http://doi.org/10.3390/ v10050218

Szych J, Wołkowicz T, Ragione RL, Madajczak G (2013) Impact of antibiotics on the intestinal microbiota and of Shiga-toxin-producing Escherichia coli and Salmonella infections treatment. Curr Pharm Design 20: 4535-4548 http://dx.doi.org/10.2174/13816128113196660730

Tinsley CR, Bille E, Nassif X (2006) Bacteriophages and pathogenicity: more than just providing a toxin? Microb Infect 8: 1365-1371. http:// doi.org/10.1016/j.micinf.2005.12.013

Węgrzyn G, Węgrzyn A (2005) Genetic switches during bacteriophage lambda development. Prog Nucl Acid Res Mol Biol 79: 1-48. http:// doi.org/10.1016/S0079-6603(04)79001-7

Węgrzyn G, Licznerska K, Węgrzyn A (2012) Phage $\lambda$ - new insights into regulatory circuits. Adv Virus Res 82: 155-178. http://doi. org/10.1016/B978-0-12-394621-8.00016-9

Weitz JS, Poisot T, Meyer JR, Flores CO, Valverde S, Sullivan MB, Hochberg ME (2012) Phage-bacteria infection networks. Trends Microbiol 21: 82-91. http://doi.org/10.1016/j.tim.2012.11.003

Zhang X, McDaniel AD, Wolf LE, Keusch GT, Waldor MK, Acheson DW (2000) Quinolone antibiotic induces Shiga toxin-encoding phages, toxin production and death in mice. I Infect Diss 181: 664 670. http://doi.org/10.1086/315239 